\title{
Identification of Competencies for Professional Staff of Academic Medical Libraries in Iran
}

\author{
Parvaneh Abotalebi', Mohammad-Hossein Biglu ${ }^{2 *}$ \\ ${ }^{1}$ Medical Library \& Information Science, Medical Philosophy and History Research Center, Tabriz University of Medical Sciences, \\ Tabriz, Iran \\ ${ }^{2}$ Research Center of Psychiatry and Behavioral Sciences, Tabriz University of Medical Sciences, Tabriz, Iran \\ Email: parvaneh2225@gmail.com, ^mh_biglu@yahoo.com
}

How to cite this paper: Abotalebi, P. and Biglu, M.-H. (2017) Identification of Competencies for Professional Staff of Academic Medical Libraries in Iran. Open Access Library Journal, 4: e3657.

https://doi.org/10.4236/oalib.1103657

Received: May 6, 2017

Accepted: June 3, 2017

Published: June 6, 2017

Copyright $\odot 2017$ by authors and Open Access Library Inc.

This work is licensed under the Creative Commons Attribution International License (CC BY 4.0).

http://creativecommons.org/licenses/by/4.0/

\begin{abstract}
Introduction: The definition of competencies is continuing to become more common in Library and Information Science (LIS). It is used for describing the library positions and the means of assessment. The main object of study was to determine the skills and knowledge that the academic medical librarians required for the emerging roles of medical librarianship in Iran and to find out their education and training needs. Methodology: A survey method was used for gathering data. A structured questionnaire, listing 60 competency statements, which covered six areas, was arranged after an extensive literature review. The structured questionnaires were sent to all academic medical librarians in Iran, those who had at least an undergraduate or Master's degree in Library Science throughout the country. A total number of 165 questionnaires were returned and went under analysis. Results. The results of study indicated that the essential competencies which were expected from Iranian academic medical librarians with Bachelor's degree qualification were "general-and personal competencies". In addition, "health science reference and information services competencies" were recognized as the second most important competencies for academic medical librarians with Bachelor's degree qualifications. However, the priority for academic medical librarians with a Master's degree qualification was "management theory and techniques competencies". The other priorities were "Health sciences reference and information services competencies". Conclusion: The study concluded that the confirmed competencies can be used for the assessment and adjustment of the curricula of formal education programs of medical librarianship in Iran.
\end{abstract}

\section{Subject Areas \\ Library, Intelligence and Philology}

\section{Keywords}

Medical Librarianship, Roles of Academic Medical Librarians, 
Knowledge and Skills, Competencies

\section{Introduction}

The rapid growth of information technologies has changed our world into a globalized village, where any kind of information can be accessed systematically. The influence of such change could be seen in the libraries more clearly than other places. We are witnessing that the prior dominant task of libraries is now done by others, including the end-users [1].

The existence of medical librarians has become a challenging issue regarding the essential point of medical information as major source of academic information in the universities all over the world. Hence training and instructing the medical librarians have become as an imperative matter in new area of technology. Nonetheless the library schools are the initiate point of preparing the information professionals for preparing them in information centers for disseminating the pertinent information regarding the clients' needs [2] [3].

We are aware that the information and communication technologies (ICTs) have influenced on any kind of professionals as well as the librarians' profession. The ICTs have impacted on accessing, managing and the dissemination of information stored in the medical libraries and have reformed the librarian roles within their workplaces [4].

In the innovative age of information science and technology, it is crucial for medical librarians to possess the necessary competencies for working in a specialized workplace, where the equipment and the clients' needs are being changing rapidly. Such changes are happening at a fast speed that every day the new skills and styles are needed to handle the information and the related ideas. The changing view point of users and the progression of new technology has enforced the professionals of library and information sciences to improve their knowledge and gain the new competencies, abilities and to improve their ability according to the new environment for copping the obsolete and outdated [5].

The essential task of medical libraries is to support the medical sciences materials which we can label it as the most dynamic disciplines. On the other hand, the working atmosphere of library and information professionals is changing into a complex environment due to the alteration nature of information. The speedy alteration of information in medical sciences causes a greater pressure on the work-place of medical librarians and enforces them to learn new techniques for improving the competencies for achieving the necessary skills [6].

It is essential to determine how the competency is defined and to discover if there is a common definition that the library and information science professionals are using due the demand of increased accountability in the libraries and the growing usage of concepts in librarians [7].

In deed the competencies were developed from the behavioral-psychology in the USA, describe the requirements of positions in an attempt to develop the 
human performances [8].

The term of "competencies" has many definitions that mirror the diverse history of the concept. It is used in clinical psychology as well as in law to represent the legal standards of mental capacity, and the ability to care for oneself, or the ability to performances in daily living activities. In professional counseling, the term of competency describes a comprehensive area of knowledge, abilities and skills that associated with specific professions. The current use of the competencies could be traced back to Griffiths and King (1985) who described the term as knowledge, skills and attitudes. Knowledge refers to the familiarity, awareness/ understanding of doing something, whereas the skill is the ability to carry out a task effectively. Attitude refers to the mental/emotional approach of a person to a situation [9]. Boyatzis (1982) defined the competency as an underlying characteristic of a person which can lead to the effective performance of a profession [10].

As emphasized by Giuse et al. (1997), there is an obligation need to the concept-based attitude rather than competency-based attitude to the education and training of medical librarians [11].

Competences are directly associated to the performance, helpfulness of performance, and the importance of the accomplished work. The capacity to the progressed competencies is taken from training, education and experience. The competencies are moderated by the rewards devoted with the performances and result of performances in the form of services or products. The performances could be tested by using a variety of administrative and appropriate factors that are termed as performance processes. The performances might influence immediate effect on a situation, service users, or forms of usage, but it might have long-term bearing which effects the organizational missions, purposes and community in a distant, indirect and unconscious method [12].

Competencies have gained the global interests through the last decade. We are witnessing that various organizations and institutes engaged themselves with competency studies for identify the competencies that are essential for making the organization to work professionally. Though there are different kinds of approaches to competencies, one of the most commonly used approaches is the competencies that are used for focusing on the people doing the work. That is, their knowledge, skills and attitudes needed to perform a work effective, rather than the work itself. This means that the factors of recognizing and affective feeling are all effective in the competencies. The most important factors of a competency are included:

- Knowledge-what a professional staff should know and understand about the subject to ensure successful accomplishment of the job.

- Skills-which are essential for processing the knowledge.

- Attitudes-The manner of thinking or feeling about the behavioural characteristics of the job [13].

Some studies emphasize that knowledge and skills should be focused by considering the competencies. Therefore the two major dimensions of competencies 
including knowledge and skills were taken into consideration in the current study for identifying the required competencies of Iranian academic medical librarians.

The main objective of this current study was to recognize the competencies that were required for the academic medical librarians in Iran. The results of study provided an overall basis for assessment of the medical library and information sciences curricula for the necessities of academic medical libraries. The results of this study would be useful for administering the MLIS departments, workplace managers and managers, and also the academic medical librarians, who are the actual beneficiaries of different features of competencies.

\section{Methodology}

The study used a survey as its research method. To explain the definition of competency for academic medical librarians, a list of required competencies that were suitable to the academic medical librarians in Iran was arranged.

After a wide-ranging review of the literature of science published through the last 2 decades, we found the instrument provided by M. Anvar \& M. Ullah [14] as a useful tool for measuring the necessary competencies of librarians; therefore some parts of the instrument that matched with the required competencies of Iranian librarians were selected as the measuring instrument of the study. The selected part of the instrument was reviewed and checked by experts. After that an instrument covering 60 competency statements in six areas was selected as the measuring instrument and was sent to the experts for validation. Every statement in the instrument had a 5-point Likert scale for remarking. The statements were checked and verified by faculty members, those who had $\mathrm{PhD}$ degrees in the field of library and Information Sciences.

The list was reviewed based on the feedback received from the experts' panel and submitted to them again for final assessment. During this workout, some competencies were removed from the list and some competencies were added to the list, based on the comments of experts' panel. The studied instrument was revised in response to the ambiguities recognized by the participants of the initial-study. They also documented some professional terms which were used in the instruments.

The structured questionnaires were sent to all academic medical sciences departments in Iran, those who had at least an undergraduate or Master's degree in Library Science throughout the country. A total number of 165 questionnaires were returned and went under analysis.

The reason of selecting the academic medical librarians as the sample of study was that, they serve a wide spectrum of clients include, students, interns, researchers, physicians, and academic members in medical sciences universities. Medical librarians engage themselves with a variety of tasks, by serving the clients whose needs are different. They are well-positioned in the institutes to recognize the changing needs and demands of the medical information services. 
According to the feed-backs received from the population of under study, the required amendments were finalized. The finalized questionnaire was developed in accordance to the objectives of the study and divided into 2 sections. The demographic part of questionnaire consisted of 7 questions and the list of competencies comprised 60 statements.

To measure the acceptability of each statement, we used a scale from 1 to 5 (not necessary to completely necessary). We took a few blank rows at the end of each area if any of the librarians may like to add other competencies.

A test and re-test were used for measuring the relativity of the research tool, which showed a high correlation rates for all components. The internal-consistency of all 60 statements was tested by Cronbach's alpha. The Cronbach's alpha values indicated a high level of internal consistency for the measuring instruments.

Each statement in the questionnaire was followed by a 5-point Likert scale, which was " 5 " for highly important, " 4 " for very important, "3" for important, " 2 " for somewhat important and " 1 " for not important. The participants were requested to select one of these options to express their opinion. The gathered data were analyzed based on the obtained average scores of the various competencies. Means and standard deviations of responses were measured by software package of SPSS version 23. A competency was considered "important" if it received an average score of greater than 4.00 . The competency statements were ranked from highest to lowest according to the mean score of academic medical librarian in both groups separately.

\section{Results}

In this section we are presenting the identified knowledge and skill and their relevant mean scores, which are presented in six different categories. The mean scores of the competencies from the perspectives of respondents were shown in the tables under each category.

Table 1 shows the mean scores for importance of competencies in the education levels (Bachelors and Masters). The statement of " Ability to evaluate library performance qualitatively and quantitatively" gained the highest mean score (4.71) in Bachelors groups and ranked the first. This was followed by "Ability to conduct environment scanning" with the mean score of 4.69.

At master's degree level, "Ability to conduct environment scanning" gained the highest mean score (4.86), which was followed by "Planning and goal-setting skills"; "Knowledge of formulating policies and procedures relating to library services" with mean scores of 4.84 and 4.83 respectively.

The competencies, which their mean scores were lower than 4.00 , were not confirmed as the required competencies.

\subsection{Health Sciences Reference and Information Services}

Table 2 shows the data relating to the mean scores of importance ratings for 
Table 1. Mean scores of management theory and techniques.

\begin{tabular}{|c|c|c|c|c|}
\hline \multirow{2}{*}{ Competency statements } & \multicolumn{2}{|c|}{ Bachelors } & \multicolumn{2}{|c|}{ Masters } \\
\hline & Mean \pm SD & Rank & Mean \pm SD & Rank \\
\hline $\begin{array}{l}\text { Ability to conduct environment scanning (a process } \\
\text { of gathering, analyzing and dispensing information } \\
\text { for tactical or strategic purposes) }\end{array}$ & $4.69 \pm 0.51$ & 2 & $4.86 \pm 0.38$ & 1 \\
\hline $\begin{array}{l}\text { Knowledge of formulating policies and procedures } \\
\text { relating to library services }\end{array}$ & $4.66 \pm 0.52$ & 3 & $4.83 \pm 0.41$ & 3 \\
\hline Planning and goal-setting skills & $4.02 \pm 0.91$ & 6 & $4.84 \pm 0.37$ & 2 \\
\hline Ability to make decisions & $3.88 \pm 0.89$ & 8 & $4.81 \pm 0.42$ & 5 \\
\hline Capability of time management \& setting priorities & $4.64 \pm 0.55$ & 5 & $3.95 \pm 0.91$ & 7 \\
\hline $\begin{array}{l}\text { Ability to prepare and manage budget and raise } \\
\text { funds from external sources }\end{array}$ & $3.73 \pm 0.95$ & 10 & $3.83 \pm 0.93$ & 10 \\
\hline \multicolumn{5}{|l|}{ Change management, that is, having the ability to } \\
\hline $\begin{array}{l}\text { Integrate library resources and services in } \\
\text { response to environmental change }\end{array}$ & $3.95 \pm 0.91$ & 7 & $3.91 \pm 0.91$ & 8 \\
\hline $\begin{array}{l}\text { Personnel management and staff development } \\
\text { (recruit, train, supervise and evaluate staff) }\end{array}$ & $3.87 \pm 0.89$ & 9 & $4.05 \pm 0.89$ & 6 \\
\hline $\begin{array}{c}\text { Ability to evaluate library performance qualitatively } \\
\text { and quantitatively }\end{array}$ & $4.71 \pm 0.53$ & 1 & $4.81 \pm 0.39$ & 4 \\
\hline Marketing of library services and resources & $4.65 \pm 0.57$ & 4 & $3.88 \pm 0.93$ & 9 \\
\hline Total & \multicolumn{2}{|c|}{$42.8 \pm 5.15$} & \multicolumn{2}{|c|}{$43.7 \pm 5.02$} \\
\hline
\end{tabular}

Table 2. Mean scores of health science reference and information services.

\begin{tabular}{|c|c|c|c|c|}
\hline \multirow{2}{*}{ Competency statements } & \multicolumn{2}{|l|}{ Bachelors } & \multicolumn{2}{|c|}{ Masters } \\
\hline & Mean \pm SD & Rank & Mean \pm SD & Rank \\
\hline $\begin{array}{l}\text { Knowledge of print and electronic reference } \\
\text { resources in health sciences }\end{array}$ & $4.76 \pm 0.42$ & 1 & $4.94 \pm 0.24$ & 1 \\
\hline $\begin{array}{c}\text { Knowledge and application of biomedical } \\
\text { informatics }\end{array}$ & $3.87 \pm 0.93$ & 8 & $3.74 \pm 0.89$ & 10 \\
\hline $\begin{array}{l}\text { Ability to conduct reference interviews and select } \\
\text { the appropriate resource to match the users' needs }\end{array}$ & $4.69 \pm 0.53$ & 4 & $4.89 \pm 0.31$ & 3 \\
\hline Ability to use medical bibliographic databases & $4.71 \pm 0.48$ & 3 & $4.94 \pm 0.25$ & 2 \\
\hline The ability to use PMDR & $3.95 \pm 0.88$ & 6 & $3.93 \pm 0.86$ & 6 \\
\hline $\begin{array}{l}\text { Expertise in information retrieval and search } \\
\text { strategy techniques }\end{array}$ & $4.71 \pm 0.53$ & 2 & $4.83 \pm 0.44$ & 4 \\
\hline $\begin{array}{l}\text { Expertise in evidence-based medical information } \\
\text { searching (identifying and retrieving latest medical } \\
\text { evidence) }\end{array}$ & $4.65 \pm 0.59$ & 9 & $3.78 \pm 0.90$ & 9 \\
\hline $\begin{array}{l}\text { Ability to develop specialized information services } \\
\text { such as selective dissemination of information } \\
\text { (SDI), current awareness/current content } \\
\text { services, bulletin boards, referral services, etc. }\end{array}$ & $3.91 \pm 0.89$ & 7 & $4.80 \pm 0.43$ & 5 \\
\hline $\begin{array}{l}\text { Resource sharing and coordination with other } \\
\text { libraries in online environment }\end{array}$ & $3.84 \pm 0.94$ & 10 & $3.85 \pm 0.90$ & 8 \\
\hline $\begin{array}{l}\text { Technical skills in the use and provide medical } \\
\text { information }\end{array}$ & $3.99 \pm 0.89$ & 5 & $3.86 \pm 0.89$ & 7 \\
\hline Total & $43.0 \pm 5.16$ & & $43.5 \pm 4$. & \\
\hline
\end{tabular}


competencies in health science reference and information services. As shown in table, the statement of "Knowledge of print and electronic reference resources in health sciences" gained the highest mean score in two groups and ranked as the first for both of them. This was followed by "Expertise in information retrieval and search strategy techniques" (4.71); and "Ability to use medical bibliographic databases" (4.71) in Bachelors groups. Regarding to the Masters group the statements of "Ability to use medical bibliographic databases" and "Ability to conduct reference interviews and select the appropriate resource to match the users' needs' gained the high mean scores of 4.94 and 4.89 respectively. Other competencies at this education level were not determined as required competencies, though their mean scores were under 4.00 .

\subsection{Management of Health Information Resources}

Table 3 shows the mean scores of importance rankings for the competencies in the area of management of health information resources. "Knowledge and application of the National Library of Medicine system of Medical Subject Headings" got the highest mean score of 4.72 in Bachelors group. This was followed by "Ability to educate users on the use of medical reference sources"; "Knowledge of copyright, licensing, privacy and intellectual property rights issues/laws"

Table 3. Mean scores of management of health information resources.

\begin{tabular}{|c|c|c|c|c|}
\hline \multirow{2}{*}{ Competency statements } & \multicolumn{2}{|c|}{ Bachelors } & \multicolumn{2}{|c|}{ Masters } \\
\hline & Mean \pm SD & Rank & Mean $\pm \mathrm{SD}$ & Rank \\
\hline $\begin{array}{l}\text { Knowledge and application of cataloguing rules, } \\
\text { standards for bibliographic formats, data } \\
\text { conversion and copy cataloguing }\end{array}$ & $3.91 \pm 0.88$ & 7 & $3.71 \pm 0.81$ & 8 \\
\hline $\begin{array}{l}\text { Knowledge of copyright, licensing, privacy } \\
\text { and intellectual property rights issues/laws }\end{array}$ & $4.68 \pm 0.49$ & 3 & $3.55 \pm 0.74$ & 10 \\
\hline $\begin{array}{c}\text { Knowledge and application of National Library } \\
\text { of Medicine (NLM) classification scheme }\end{array}$ & $4.68 \pm 0.56$ & 4 & $4.60 \pm 0.54$ & 4 \\
\hline $\begin{array}{l}\text { Knowledge and application of the National Library } \\
\text { of Medicine system of Medical Subject Headings }\end{array}$ & $4.72 \pm 0.52$ & 1 & $4.73 \pm 0.47$ & 1 \\
\hline $\begin{array}{l}\text { Ability to educate users on the use of medical } \\
\text { reference sources }\end{array}$ & $4.69 \pm 0.53$ & 2 & $4.66 \pm 0.55$ & 2 \\
\hline $\begin{array}{l}\text { Knowledge of resource maintenance, safety, } \\
\text { conservation and preservation techniques }\end{array}$ & $3.94 \pm 0.82$ & 6 & $4.64 \pm 0.50$ & 3 \\
\hline $\begin{array}{l}\text { Knowledge of weeding practice (discarding and } \\
\text { writing off unusable and obsolete materials) }\end{array}$ & $3.71 \pm 0.88$ & 10 & $4.58 \pm 0.61$ & 5 \\
\hline Capability of indexing \& abstracting of documents & $3.80 \pm 0.91$ & 9 & $3.71 \pm 0.78$ & 7 \\
\hline $\begin{array}{l}\text { Knowledge of serials management and operation } \\
\text { (ordering, claiming, invoicing, renewal, holdings } \\
\text { reports, binding, etc.) }\end{array}$ & $3.86 \pm 0.87$ & 8 & $3.63 \pm 0.80$ & 9 \\
\hline $\begin{array}{l}\text { Ability to operate the process of circulation } \\
\text { (registration, issue, return, reservation, } \\
\text { overdue notices and fine management) }\end{array}$ & $4.66 \pm 0.58$ & 5 & $3.90 \pm 0.85$ & 6 \\
\hline Total & $42.6 \pm$ & & $41.7 \pm$ & \\
\hline
\end{tabular}


with mean scores of 4.69 and 4.68 respectively.

Among the competencies, at Master's degree, the highest mean score belonged to the statement of "Knowledge and application of the National Library of Medicine system of Medical Subject Headings" (4.73). This was followed by "Ability to educate users on the use of medical reference sources" (4.66). Other competencies at this education level were not measured as the required competencies, since their mean scores were under 4.00 .

\subsection{Information Systems and Technologies}

Table 4 shows the mean scores of importance ratings for information systems and technologies competencies in two levels of education (Bachelors and Masters). "Knowledge of telecommunication and networking" gained the highest mean score of 4.75 in Bachelors group. This was followed by "Using MS Office" (4.68) and Basic knowledge of and ability to use expert systems (4.67). Considering the Master's degree level, the competency which ranked as the first was "Using MS Office" (4.83). This was followed by "knowledge of telecommunication and networking" (4.80). Other competencies at this education level were not measured as required competencies for receiving the mean scores under 4.00.

Table 4. Mean scores of information systems and technologies.

\begin{tabular}{|c|c|c|c|c|}
\hline \multirow{2}{*}{ Competency statements } & \multicolumn{2}{|c|}{ Bachelors } & \multicolumn{2}{|c|}{ Masters } \\
\hline & Mean \pm SD & Rank & Mean $\pm \mathrm{SD}$ & Rank \\
\hline $\begin{array}{l}\text { Knowledge of Integrated Library } \\
\text { Automation Systems }\end{array}$ & $3.92 \pm 0.88$ & 7 & $4.74 \pm 0.44$ & 4 \\
\hline $\begin{array}{l}\text { Understanding of digitization technology and } \\
\text { management programs to create digital resources }\end{array}$ & $4.65 \pm 0.57$ & 4 & $3.81 \pm 0.88$ & 8 \\
\hline $\begin{array}{l}\text { Knowledge and understanding of Internet } \\
\text { for library use (e-mail, discussion groups, } \\
\text { search engines, web resources) }\end{array}$ & $3.82 \pm 0.92$ & 8 & $3.84 \pm 0.87$ & 7 \\
\hline knowledge of telecommunication and net working & $4.75 \pm 0.48$ & 1 & $4.80 \pm 0.40$ & 2 \\
\hline $\begin{array}{c}\text { Knowledge and application of Web } 2.0 \text { technology } \\
\text { in libraries (Library } 2.0 \text { ) }\end{array}$ & $3.96 \pm 0.89$ & 6 & $3.88 \pm 0.84$ & 6 \\
\hline $\begin{array}{l}\text { Ability to manage automated systems (input, file } \\
\text { maintenance, backup, security, etc.) }\end{array}$ & $3.73 \pm 0.93$ & 10 & $3.75 \pm 0.89$ & 9 \\
\hline $\begin{array}{l}\text { Ability to use barcodes and RFID (radio frequency } \\
\text { identification) technologies for libraries }\end{array}$ & $4.64 \pm 0.61$ & 5 & $4.69 \pm 0.49$ & 5 \\
\hline $\begin{array}{l}\text { Using MS Office (MS Word, MS Excel, MS Power } \\
\text { point) and In page (an Urdu word processor) }\end{array}$ & $4.68 \pm 0.58$ & 2 & $4.83 \pm 0.38$ & 1 \\
\hline $\begin{array}{l}\text { Basic knowledge of and ability to use expert } \\
\text { systems(software that finds information like a } \\
\text { human expert in the field to solve problems) }\end{array}$ & $4.67 \pm 0.64$ & 3 & $4.79 \pm 0.44$ & 3 \\
\hline Web page/portal designing and maintenance skills & $3.74 \pm 0.92$ & 9 & $3.65 \pm 0.88$ & 10 \\
\hline Total & $42.5 \pm$ & & $42.7 \pm$ & \\
\hline
\end{tabular}




\section{Research Methods}

Table 5 shows the data relating to the mean scores of importance ratings for the research competencies. Among the competencies in Bachelor's degree level, "Understanding the needs of library research" achieved the highest mean score of 4.53. This was followed by "Understanding the principles and methods of research" with the mean score of 4.49. As shown in Table 5, in Master's degree, the "Basic understanding of research methodologies" achieved the highest mean score of 4.66. This was followed by: "Understanding the needs of library research"; "Ability to use research tools such as questionnaires, focus groups and interviews to conduct user's studies" with mean scores of 4.65 and 4.64 respectively. Other competencies at this education level were not measured as the required competencies as their mean scores were under 4.00 .

\section{General and Personal Competencies}

Table 6 shows the mean scores of importance ratings of competencies for two levels of education inclusive the Bachelors and Masters degrees. The statement "Commitment to service excellence" got the highest mean score from the both groups and ranked as the first in both of them. This was followed by "Sense of humor" (4.79); and "Eager to learn new skills" (4.73) in Bachelors groups. Considering the Masters group, the statement of "Sense of humor" and "Capacity to take initiatives and risks" got the highest mean scores of 4.78 and 4.75 respectively. Other competencies at this education level were not confirmed as required

Table 5. Mean scores of research method.

\begin{tabular}{|c|c|c|c|c|}
\hline \multirow{2}{*}{ Competency statements } & \multicolumn{2}{|c|}{ Bachelors } & \multicolumn{2}{|c|}{ Masters } \\
\hline & Mean \pm SD & Rank & Mean \pm SD & Rank \\
\hline $\begin{array}{l}\text { Basic understanding of research methodologies } \\
\text { (both quantitative and qualitative) }\end{array}$ & $4.44 \pm 0.66$ & 3 & $4.66 \pm 0.55$ & 1 \\
\hline $\begin{array}{l}\text { Understanding the principles and } \\
\text { methods of research }\end{array}$ & $4.49 \pm 0.62$ & 2 & $4.14 \pm 0.82$ & 6 \\
\hline Understanding the needs of library research & $4.53 \pm 0.58$ & 1 & $4.65 \pm 0.53$ & 2 \\
\hline $\begin{array}{l}\text { Basic knowledge of descriptive and } \\
\text { inferential statistics }\end{array}$ & $3.59 \pm 0.86$ & 10 & $3.71 \pm 0.73$ & 10 \\
\hline $\begin{array}{l}\text { Ability to use research tools such as questionnaires, } \\
\text { focus groups and interviews to conduct } \\
\text { user's studies }\end{array}$ & $3.88 \pm 0.89$ & 7 & $4.64 \pm 0.48$ & 3 \\
\hline $\begin{array}{l}\text { Knowledge and application of data analysis } \\
\text { software (SPSS, Instate etc) }\end{array}$ & $3.60 \pm 0.91$ & 9 & $3.91 \pm 0.86$ & 9 \\
\hline $\begin{array}{l}\text { Knowledge and application of citation styles and } \\
\text { reference managers (endnote, Procite, etc.) }\end{array}$ & $4.36 \pm 0.78$ & 4 & $4.64 \pm 0.53$ & 4 \\
\hline Ability to write research reports & $4.35 \pm 0.76$ & 5 & $3.91 \pm 0.84$ & 8 \\
\hline Knowledge hypotheses and research questions & $3.69 \pm 0.84$ & 8 & $4.03 \pm 0.82$ & 7 \\
\hline Familiarity with note-taking & $3.93 \pm 0.85$ & 6 & $4.64 \pm 0.53$ & 5 \\
\hline Total & $40.8 \pm$ & & $42.9 \pm$ & \\
\hline
\end{tabular}


Table 6. Mean scores of general and personal competencies.

\begin{tabular}{|c|c|c|c|c|}
\hline \multirow{2}{*}{ Competency statements } & \multicolumn{2}{|c|}{ Bachelors } & \multicolumn{2}{|c|}{ Masters } \\
\hline & Mean \pm SD & Rank & Mean \pm SD & Rank \\
\hline Commitment to service excellence & $4.81 \pm 0.45$ & 1 & $4.81 \pm 0.39$ & 1 \\
\hline Sense of humor & $4.79 \pm 0.46$ & 2 & $4.78 \pm 0.42$ & 2 \\
\hline Eager to learn new skills & $4.73 \pm 0.52$ & 3 & $4.73 \pm 0.44$ & 4 \\
\hline $\begin{array}{c}\text { Knowledge and commitment to professional } \\
\text { ethics and values }\end{array}$ & $3.85 \pm 0.93$ & 9 & $4.06 \pm 0.89$ & 7 \\
\hline $\begin{array}{l}\text { Commitment to lifelong learning and } \\
\text { career planning }\end{array}$ & $4.11 \pm 0.92$ & 6 & $4.71 \pm 0.50$ & 5 \\
\hline Capacity to take initiatives and risks & $4.67 \pm 0.58$ & 5 & $4.75 \pm 0.46$ & 3 \\
\hline Adaptability to change & $3.93 \pm 0.94$ & 8 & $3.58 \pm 0.79$ & 10 \\
\hline Ability to have creative thinking & $3.78 \pm 0.91$ & 10 & $3.68 \pm 0.82$ & 9 \\
\hline $\begin{array}{l}\text { Capability to work independently } \\
\text { and under pressure }\end{array}$ & $4.04 \pm 0.90$ & 7 & $3.79 \pm 0.86$ & 8 \\
\hline $\begin{array}{l}\text { Participation in professional activities } \\
\text { outside the library }\end{array}$ & $4.73 \pm 0.49$ & 4 & $4.15 \pm 0.84$ & 6 \\
\hline Total & $43.4 \pm$ & & $43.0 \pm$ & \\
\hline
\end{tabular}

competencies, because their mean scores were under 4.00 .

\section{Discussion}

Competencies are recognized to define the standards of skills, knowledge, and attitudes prerequisite for the performance of tasks by individuals for which they are employed. These are clearly mirrored in the curriculum of academic institutions for grounding the future professionals. They may help to the elimination of the gaps between the required capabilities and the available translating competencies in the training and education programs to prepare the coming professionals with necessary knowledge and skills.

This study investigated the skills and knowledge required by academic medical librarians in two different levels of MLIS education.

The results of study showed that the validation of 10 statements gained the higher mean scores regarding to the management competencies which were expected from academic medical librarians in Iran (Table 1). Among the management-competencies, the most expected skills were "Ability to evaluate library performance" and "Ability to conduct environment scanning". These findings of study were in consistent with the results of studies conducted by Roper and Mayfield [15], Guise, et al. [11], Santra [16] and de Grandboisis [17], Ullah and Anvar [18].

The study furthermore indicated that the "Health sciences reference and information services" competencies were recognized important for academic medical librarians in both groups of respondents. It means that all academic medical librarians should sufficiently train themselves with such capabilities (Table 2). 
The high level of mean scores for detection the competency statements about the knowledge of reference resources, retrieval skills, knowledge of medical databases/resources and reference interview indicated that the participants were agree about the importance these statements. However, the competency statements of "Expertise in evidence-based medical information searching" and "knowledge and application of biomedical informatics", achieved the low mean scores. This may be due to the probability that such perceptions were new to the librarians.

Furthermore, the study revealed that the "Management of health information resources competencies" was at the lower mean score among masters group. "Knowledge and application of NLM classification scheme and MeSH" seem to be highly important for academic medical librarians, as perceived by bachelor groups of respondents (Table 3). These findings of study were in consistent with the results of the study conducted by Khoo [19].

Our results show that participants considered very measured important the statement of 'knowledge and skills of emerging technologies for providing the timely and quality information services (Table 4). Information technology plays major role in establishment of information-systems, databases, virtual-libraries, digitization and development the web portals. It is remarkable to declare that the "Ability to manage automated systems" and "web page/portal designing and maintenance skills" competencies were not validated as important statement by participants.

These findings are generally consistent with a number of studies have addressed the importance of information technology competencies for postgraduate librarians [20] [21] [22] [23]. In addition, Mazinani [24], Rehman et al., [25] and Singh and Mehra's [26] studies recognized the information technology as an important competency in LIS education.

Furthermore, the research competencies were highlighted for academic medical librarians with a master degree qualification, while these competencies were not confirmed as needed competencies for librarians with bachelor degree qualification (Table 5). This finding of the study was in consistent with the study of Bronstein [27]. This may be due to the lack of research attitudes of librarians in Iran. Ther librarians also do not involve themselves with research activities. This result is disagreement with the findings of Partridge et al. [28], WebJunction [20] and special libraries association [22] that specified the importance of research competencies for postgraduate librarians.

The general and personal competencies' were measured highly important among bachelor group (Table 6). This finding of study was in agreement with the results of study conducted by Pellack [29].

The study indicated that the medical librarians need to have suitable personal qualities in their professions and to enhance their credibility, for becoming acceptable members of teams in the organisations.

\section{Conclusion}

The medical library and information science (MLIS) education in Iran is offered 
in 3 education levels, i.e. Bachelors, Masters, and PhD. Analysis of our literature review indicated that the studied competencies in the field have mainly focused on the competencies needed by the librarians with postgraduate qualifications. Therefore, the results of this current study would be very important due to the presentation of an insight into criteria of assessment for the existing MLIS training and education programs.

The results of the current study indicated that Iranian MLIS departments should endeavor to re-evaluate the curriculum at different levels of education.

In conclusion it is recommended such a study to be replicated in order to identify the required competencies of other library settings in Iran.

\section{Limitations of the Study}

This study has some limitations. First its' main aim was restricted to recognizing and assessing the competencies which were needed only for the academic medical librarians in Iran. Second, the study did not determine the weightage of each competency that should be considered for the MLIS curriculum. Furthermore it was not planned to define a detailed content for each competency.

\section{References}

[1] Biglu, M.H. (2008) Scientometric Study of Patent Literature in MEDLINE \& SCI. Doctoral Dissertation, Humboldt-Universität zu Berlin, Philosophische Fakultät I.

[2] Homan, J.M. and McGowan, J.J. (2002) The Medical Library Association: Promoting New Roles for Health Information Professionals. Bulletin-Medical Library Association, $90,80-85$.

[3] Detlefsen, E.G. (2002) The Education of Informationists, from the Perspective of a Library and Information Sciences Educator. Bulletin-Medical Library Association, 90, 59-67.

[4] Buttlar, L. and Du Mont, R. (1996) Library and Information Science Competencies Revisited. Journal of Education for Library and Information Science, 37, 44-62. https://doi.org/10.2307/40324283

[5] Singh, S. and Pinki, H. (2004) New Skills for LIS Professionals in Technology-Intensive Environment. 2nd International CALIBRE, New Delhi, India, INFLIBNET CENTRE, Ahmedabad.

[6] Lindberg, D.A. and Humphreys, B.L. (2005) 2015-The Future of Medical Libraries. New England Journal of Medicine, 352, 1067-1070. https://doi.org/10.1056/NEJMp048190

[7] Stoffle, C.J., Allen, B., Morden, D. and Maloney, K. (2003) Continuing to Build the Future: Academic Libraries and Their Challenges. Portal: Libraries and the Acade$m y, 3,363-380$. https://doi.org/10.1353/pla.2003.0068

[8] Rothwell, W.J. and Lindholm, J.E. (1999) Competency Identification, Modelling and Assessment in the USA. International Journal of Training and Development, 3 , 90-105. https://doi.org/10.1111/1468-2419.00069

[9] Griffiths, J.-M. and King, D.W. (1985) New Directions in Library and Information Science Education. Final Report: ERIC.

[10] Boyatzis, R.E. (1982) The Competent Manager: A Model for Effective Performance. John Wiley \& Sons, New York. 
[11] Giuse, N.B., Huber, J.T., Kafantaris, S.R., Giuse, D.A., Miller, M.D., Giles, D.E., et al. (1997) Preparing Librarians to Meet the Challenges of Today's Health Care Environment. Journal of the American Medical Informatics Association, 4, 57-67. https://doi.org/10.1136/jamia.1997.0040057

[12] Rehman, S., Majid, S. and Baker, A.B.A. (1999) Competencies for Public Library Professionals in Malaysia. Public Library Quarterly, 17, 63-80. https://doi.org/10.1300/J118v17n02_08

[13] Bryant, J. and Poustie, K. (2001) Competencies Needed by Public Library Staff: Bertelsmann Foundation.

[14] Anwar, MA. and Ullah, M. (2017) Developing an Instrument for the Validation of Competencies: The Case of Medical Librarians.

[15] Roper, F.W. and Mayfield, M.K. (1993) Surveying Knowledge and Skills in the Health Sciences: Results and Implications. Bulletin of the Medical Library Association, 81, 396.

[16] Santra, N. (2007) Academic Medical Librarians in Malaysia: What Roles Do They Play? Malaysian Journal of Library \& Information Science, 12, 83.

[17] de Grandbois, Y. (2013) Managerial Competencies for Information Professionals: An International Perspective. Library Review, 62, 335-343. https://doi.org/10.1108/LR-06-2012-0023

[18] Ullah, M. and Anwar, MA. (2013) Developing competencies for medical librarians in Pakistan. Health Information \& Libraries Journal, 30, 59-71.

[19] Khoo, C. (2005). Educating LIS Professionals for Singapore and Beyond. Celebrating, 50, 26-37.

[20] Gutsche, B. and Hough, B., Eds. (2014) Competency Index for the Library Field. OCLC, Dublin, $\mathrm{OH}$.

https://www.webjunction.org/content/dam/WebJunction/Documents/webJunction/ 2014-03/Competency-Index-2014.pdf

[21] American Association of Law Libraries (2010) Competencies of Law Librarianship. http://www.aallnet.org/mm/Leadership-Governance/policies/PublicPolicies/compet encies.html

[22] The Special Libraries Association (1996) Competencies for Special Librarians of the 21st Century. SLA, Washington DC.

[23] ALA (2009) ALA's Core Competences of Librarianship. Retrieved 21 August 2010, 284.

[24] Mazinani, A. (1998) Skills Required by Librarians Working in Iranian Academic Libraries and Information Centers. National Studies on Librarianship and Information Organization, 9, 44-64.

[25] Rehman, S., Majid, S. and Baker, A.B.A. (1998) Competency Definition and Validation for Library and Information Professionals in Malaysia. Journal of Education for Library and Information Science, 39, 100-117. https://doi.org/10.2307/40324167

[26] Singh, V. and Mehra, B. (2013) Strengths and Weaknesses of the Information Technology Curriculum in Library and Information Science Graduate Programs. Journal of Librarianship and Information Science, 45, 219-231. https://doi.org/10.1177/0961000612448206

[27] Bronstein, J. (2015) An Exploration of the Library and Information Science Professional Skills and Personal Competencies: An Israeli Perspective. Library \& Information Science Research, 37, 130-138. https://doi.org/10.1016/j.lisr.2015.02.003

[28] Partridge, H., Lee, J. and Munro, C. (2010) Becoming "Librarian 2.0": The Skills, 
Knowledge, and Attributes Required by Library and Information Science Professionals in a Web 2.0 World (and Beyond). Library Trends, 59, 315-335.

[29] Pellack, L.J. (2004) Interpersonal Skills in the Reference Workplace. The Reference Librarian, 40, 57-70. https://doi.org/10.1300/J120v40n83_06

Submit or recommend next manuscript to OALib Journal and we will provide best service for you:

- Publication frequency: Monthly

- 9 subject areas of science, technology and medicine

- Fair and rigorous peer-review system

- Fast publication process

- Article promotion in various social networking sites (LinkedIn, Facebook, Twitter, etc.)

- Maximum dissemination of your research work

Submit Your Paper Online: Click Here to Submit

Or Contact service@oalib.com 